Mongolian Academy of Sciences
Mongolian Journal of Chemistry
Institute of Chemistry \& Chemical Technology

\title{
The Quality and Safety of Imported Food: The Danger of Pesticides
}

\author{
Batgerel Dugar ${ }^{1}$ \\ ${ }^{I}$ The head of united laboratory of Borders specialized inspection department in Zamin-Uud; \\ E-mail: batgerel.dugar@yahoo.com
}

\begin{abstract}
The analysis of pesticide residue in imported food by thin layer chromatography is reported in this work. The pesticide residue was found in 34 samples of 11 kinds fresh harvested vegetables during fall of 2011.
\end{abstract}

Keywords: pesticides, pesticide residue, thin layer chromatography

\section{Introduction}

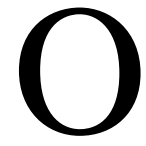

ne of primary concerns of national security is the quality of food products. Especially in Mongolia, over $70 \%$ of imported food products supplying to whole country are transported through the border at Zamiin-Uud (from a report of food products which were transported through the Zamiin-Uud border: Specialized Inspection Station during 20082009).

Due to the current economic crisis and lack of goods produced in Mongolia, the Mongolian Government has collected taxes from both individuals and merchant groups participating in international trade for completing state budget. However, the quality and safety of imported products is left outside the control.

Generally, most of the Mongolia people do not have the ability to examine safe and unsafe food products. Only the apparent quantity and price of goods are taken into consideration. Moreover, the inspection control of the Mongolian Border Control has weakened over the past 20 years. To these reasons, Mongolians are unexpected consuming either contaminated or expired food. New research, recently released by the
Health Ministry, shows that the Mongolians are suffering from unknown illnesses and the average age of the young patient is getting lower.

Since the Mongolia's economic situation has been improving, the government declared the 2008 as "The Year of Food Security" while two billion tugrugs has been donated to the Zamiin-Uud Border Specialized Inspection Station. Recently, the government has announced its plan to "Bringing virgin land under cultivation" and has given support to farmers who plant potatoes, vegetables and wheat. Measures have also been taken to improve laboratories efficiency and procedures of the State Specialized Inspection Department and Border Specialized Inspection Stations. So far, the influence of imported food quality has positively revealed. However, there are still many problems related to food delivered to Mongolia as follow:

a. Imported foods do not meet national health standard.

b. Mongolia must reach global development standards for food quality and safety. 
c. Genetically altered foods are not compatible with Mongolian physiology.

d. Currently, Mongolian Inspection teams cannot strictly perform the controlling procedures of all products which are necessary to consistently provide customers with safe products.

e. Mongolian Inspection teams cannot assess national requirements and the appropriate standards for new types of genetically altered food.

f. The optimum food consumption must be determined.

g. The quantity of genetically altered food that is imported into Mongolia must be, in fact, determined.

Some goods imported to Mongolia through the Zamiin-Uud Border Specialized Inspection Station from January to September 2011 are shown in the following lists:

- $66.82 \% \quad(581072$ t) Construction materials

- $8.9 \%$ (78634.1 t) Plant products and vegetables

- $0.9 \% \quad(8195.2 \mathrm{t})$ Both raw and processed animal products

- $3,5 \% \quad(31147.8$ t $)$ Chemical substances

- $9.5 \%$ ( $3842222.01 \mathrm{t}$ ) Processed food products

- $\quad 0.5 \%$ (4949.5 t) Beauty products and household goods

- $0.08 \%$ ( 760.5 t) Medicine and medical equipment of all imported products.

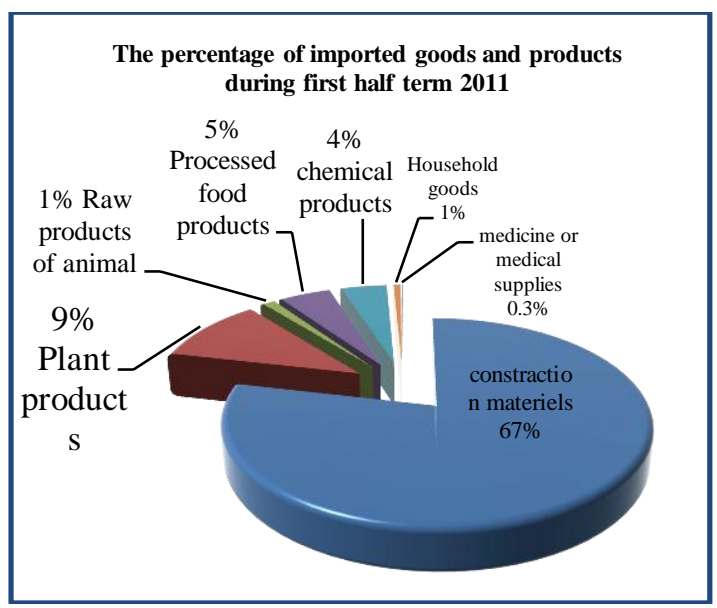

Figure1. The percentage of imported goods and products during first half of 2011.
- $9 \%$ Plant products

- $1 \%$ Raw products of animal

- $5 \%$ Processed food products

- $4 \%$ Chemical products

- $1 \%$ Household goods

- $3 \%$ Medicine or medical supplies

- $67 \%$ Construction materials

- $12 \%$ or 118722.01 ton of total imported goods is food products and $48.3 \%$ or 57452.7 ton of those were transported by trucks.

Food products which were tested in Zamiin-Uud Border Specialized Inspection Station Laboratory are:

- $70.6 \%$ Plants, for example: potatoes, vegetables, fruits and berries

- 29.4\% Processed food products, for example: canned food, jam and noodles etc

Also $34.3 \%$ or 19659.3 ton of all food products were transported by trucks. And were tested in Zamiin -Uud Border Specialized Inspection Laboratory.

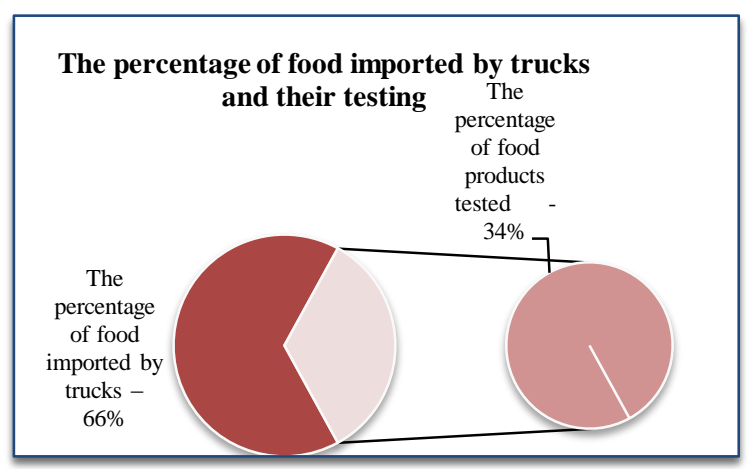

Figure 2. The percentage of food delivered by trucks and its inspection:

- The percentage of food imported by trucks- $66 \%$

- The percentage of food products tested- $34 \%$ out of total $66 \%$

The laboratories of the Zamiin-Uud Border Specialized Inspection Station tested the chloroorganic and phosphorous pesticide residue of potatoes, vegetables, fruits and berries by using the MNS4933:99 and MNS4932:99 standard method, thin layer chromatography. 


\section{Experimental}

Researching methodology is based on the following procedures:

\section{Materials:}

Prepare $500 \mathrm{~g}$ of smashed vegetables or fruits for each set of testing

1. Put $20 \mathrm{~g}$ smashed vegetables or fruits into $250 \mathrm{ml}$ dividing funnel.

2. Add $30 \mathrm{ml}$ hexane and shake carefully for 15 minutes.

3. Add $10 \mathrm{ml}$ sulphuric acid and shake for $1 \mathrm{~min}$.

4. Rinse stratum with hexane must be 23 times by $20 \mathrm{ml}$ distilled water. The organic stratum is allowed to go through the evaporated.

5. Dry residues are dissolved in the 0.2 $\mathrm{ml}$ diethyl ether.

\section{Chloroorganic pesticide preparation:}

1. Prepare chloroorganic pesticide solution from agricultural sample by organic solvent extraction

2. Put the sample in the silica gel shallow stratum and burn under ultraviolet ray lamp $(254 \mathrm{~nm})$

3. Investigate the components of sample by comparing with standard solution using thin layer chromatography

I. Preparing standard solution of chloroorganic pesticide by put 10 $\mathrm{ml}$ chlororganic pesticide into the glass tube and fill with hexane till the line.

II. Indicator solution preparation Combine $10 \mathrm{ml}$ nitric silver with 5 $\mathrm{ml}$ distilled water in the glass tube. Then add $7 \mathrm{ml}$ of ammonia concentration and fill acetone till the line.

Thin layer chromatography:

1. Prepared sample is dropped slowly with

micro syringe on the dot no more 0.5 $\mathrm{cm}$ diameter in a distance $1.5 \mathrm{~cm}$ from the below edge of a shadow stratum chromatograph plate.

2. Two pesticide standard model solutions are dropped on the both side of experimental sample. N-hexane is put into the camera by running solution, but 6:1 hexane and acetone mixture (if pesticide $R_{\mathrm{f}}$ is less than 0.3 ) before $30 \mathrm{~min}$ of chromatograph procedure. In the chromatograph camera, plate is located in the condition. When solubility is raised 10 $\mathrm{cm}$ up, plate is taken out of the camera and dried. Finally, the plate is sprayed with silver nitrate solution and burned under a ultra-violet ray's lamp $(254 \mathrm{~nm})$ with a distance $20 \mathrm{~m}$ for 10 $15 \mathrm{~min}$.

In this way, black and grey spot of chloroorganic pesticide is appeared on the plate. Size of chloroorganic pesticide which is contained in the sample was counted by following equation;

$$
X=\frac{A}{P}
$$

where $\mathrm{X}$ is size of pesticide in a simple $\mathrm{A}$ is amount of standard solution And $\mathrm{P}$ is size of sample

\section{Results and Discussion}

From the tested food products which were tested in the Zamiin-Uud Border Specialized Inspection Station laboratory,

- $70.6 \%$ was plant yield food, for example; potatoes, vegetables, fruit and berries

- $\quad 29.4 \%$ was processed food products

$34.3 \%$ of all food products were transported by trucks and were tested in Zamiin-Uud Border Specialized Inspection laboratory. The percentage of food delivered by trucks and its inspection is shown in Figure 1.

1. The percentage of food imported by truck $66 \%$

2. The percentage of food products tested $34 \%$

Just $34 \%$ of all truck transported food imported through Zamiin -Uud was tested in the Border laboratory which consequently gives the following questions:

- Is portion of the $66 \%$ of the food products passed through Zamiin-Uud Customs Station without inspection meet healthy food requirements?

- Can we certain that products transferred through Inland [deep] Customs Central Station? 
- In Mongolia there are 5 international and 8 bi-national border customs stations of those Border stations, 7 are permanent while the others are open seasonally.

How many of these customs stations have the equipment and resources necessary to properly test imported food products?

The laboratories of the Zamiin Uud Border Specialized Inspection Station tested the chloro-organic and phosphorous pesticide residue in potatoes, vegetables, fruit and berries by using the MNS4833: 99, and MNS4832: 99 standard methods which are thin layer chromatography method.

During first 9 months of 2011, 427 samples from 24 kinds of food products were tested at the Zamiin-Uud Border Laboratory. However, they did not meet the standard requirements. Only 9\% of the total imports were tested and none of them met standard and health requirements.

Pesticide residue was found in fresh harvested vegetables during fall of 2011. There were 24 samples from 11 kinds of vegetables with pesticide. $7.9 \%$ of all these 34 samples of vegetables, fruits and berries didn't meet health and safety standards. Moreover, they are $7.9 \%$ of all food samples didn't meet requirements and $3.1 \%$ of all tested vegetables, fruits and berries samples by using thin layer chromatography method in Zamiin-Uud Border Laboratory during first 9 months of 2011.

Table 1 . Types and quantity of plant products with pesticide remains

(January-September 2011)

\begin{tabular}{|c|c|c|c|c|}
\hline & Items & $\begin{array}{c}\text { Number } \\
\text { of tested } \\
\text { samples }\end{array}$ & $\begin{array}{c}\text { Number } \\
\text { of samples } \\
\text { with } \\
\text { pesticide }\end{array}$ & $\begin{array}{c}\text { Result of } \\
\text { testing } \\
\text { HOP }\end{array}$ \\
\hline 1 & Potatoes & 53 & 7 & Discovered \\
\hline 2 & Onion & 219 & 3 & Discovered \\
\hline 3 & Carrots & 68 & 5 & Discovered \\
\hline 4 & Tomatoes & 184 & 6 & Discovered \\
\hline 5 & Kiwi & 14 & 1 & Discovered \\
\hline 6 & Cucumbers & 96 & 3 & Discovered \\
\hline 7 & Peach & 9 & 2 & Discovered \\
\hline 8 & Pepper & 131 & 2 & Discovered \\
\hline 9 & Cabbage & 221 & 2 & Discovered \\
\hline 10 & Grapes & 13 & 2 & Discovered \\
\hline 11 & Pear & 56 & 1 & Discovered \\
\hline 12 & Total & 1064 & 34 & \\
\hline
\end{tabular}

\section{Conclusions}

Only $34 \%$ of all truck transported food through Zamiin-uud was tested in the Border laboratory which consequently caused the following problems:

- What portion of the $66 \%$ of the food products passed through Zamiin-Uud Customs station without inspection meet healthy food requirements?

- Can we be certain that products transferred through Inland (deep) Customs Central Station are thoroughly tested?

- In Mongolia there are 5 international and 8 binational border customs station. Of these Border stations 7 are permanent, others are open seasonally

How many of these customs stations have the equipment and resources necessary to properly test imported food products? To solve these problems, the following steps should be taken:

1. We should establish a fully-equipped Border Specialized Inspection laboratory in every border customs station in Mongolia.

2. Improve the thoroughness of control on imported food products.

3. All imported food products must be tested completely.

4. Increase the capacity of Border Inspection Laboratories.

5. Train laboratory researchers and address the staff turnover problems.

$90 \%$ of all imported vegetables and fruit were imported by private merchants using the trucks. The quality and safety of the products was never mentioned in their contracts. Special permission for importing food products should be granted to professional experts and companies.

Although the government has improved the infrastructures and staff capacity of Border Specialized Inspection Stations and their laboratories, foreign trade documents should be reviewed again, according to these results. We should stop promoting the idea that imported foreign food is best. These goods can cause illnesses and other health issues due to their genetically altered nature. 
Finally, the biggest danger is the careless of proper inspection procedures. Other nations could use altered foods cause damage to Mongolia's national health and security.

\section{References}

1. B.M Poznyakovskii "Gigienicheskiye osnovi pitaniya bezopasnosti I ekspertiza pishevih produktov" Novosibirsk-2002, pp 190-198
2. Melnicov. N. N, "Chemical technology of pesticides" 1974, pp 6070 ;

3. Lindan: Monographic eider insecticide Werkstoffs. Hrsg. Von E. ulmann, Freiburg, 1973.

4. O.Mikes "Chromatographic and allied methods" Chichester-New York Brisbane-Toronto, pp 462-498

5. www.chemport.ru/chemical_encyclop edia_article_791.html

6. N.Tsevegsuren, I.Saruul "Food Toxicology and Health", Ulaanbaator. 2004 year 